\section{Botanical Imperialism}

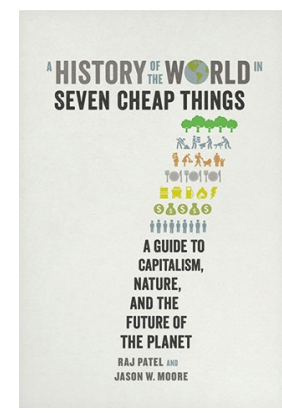

\author{
A History of the \\ World in Seven \\ Cheap Things: A \\ Guide to Capitalism, \\ Nature, and the \\ Future of the Planet \\ By Raj Patel and Jason \\ W. Moore \\ VERSO: 2018. 312PP. \\ E16.99.
}

$\mathrm{B}$ uzzwords like 'sustainability' and 'neoliberalism' have become so commonplace as to lose their meaning in today's environmental and economic discourse. In A History of the World in Seven Cheap Things, Patel and Moore argue that another potential buzzword 'Anthropocene' - poses the danger of not just being meaningless, but also of disguising the true nature of how humans are changing both the human and natural world. In its place they would posit that we live, instead, in the 'Capitalocene' era. Their argument is rooted in over 500 years of imperial and industrial history in which capitalism has made objects, lives and nature profoundly cheap, in the sense of being devalued.

The central conceit of the book is that each of the eponymous seven cheap things, from food to money to lives, can be traced back to, or at least exemplified by, Christopher Columbus' exploitation of indigenous peoples in both Madeira and the West Indies. Much of this exploitation was for a crop that became a central component of the Atlantic Trade and helped multiple nations become industrial superpowers: sugar. Sugar was grown and exported using aggressive techniques that scarred both the land and the people who worked, and died, on it. The success of this type of agriculture and economic system spread almost without conscious effort, spurred on by the quest for ever-increasing profit on the frontiers of empires.

That the book is sometimes repetitive in its main argument - and its insistence that Columbus was history's greatest monster, to the exclusion of others who could just as easily fit that bill - does not detract from the comprehensive picture that the authors paint of how all-encompassing capitalism has become in defining and governing how we relate to each other and to nature. The chapter on cheap food is eye-opening in its own right, exposing how the British famines in Ireland and India in the 1800s were in many ways precursors to the Green Revolution, which we now know increased hunger and poverty for millions while protecting and increasing crop exports for global markets. We also see how without cheap energy, industrial agriculture cannot supply the cheap food that provides the cheap labour that is mined, in countries of all income and development levels, for profit. The true strength of capitalism lies in its interconnections, each cheap object reinforcing the other; the same is true for each chapter here, with the examples and historical narrative building to an inescapable conclusion. This is a stunning book that will be a foundational text in world ecology studies for years to come.

Reviewed by Ryan Scarrow

Published online: 5 June 2018

https://doi.org/10.1038/s41477-018-0173-2 